護上若干問題があることが判明した.

\section{結語}

術後早期の血清 CPK および LDH アイソザイム分 析の結果，超低体温・低流量灌流法では大動脈遮断時間 90 分以内の範囲では心筋保護上充分安全とい党る.

これに対してバィパス併用超低体温法では循環遮断時 間が 60 分をこ党る症例では，MB-CPK に関しては許
容範囲内にあるが， $\left(\mathrm{LDH}_{1}+\mathrm{LDH}_{2}\right)$ 分画の増加がみら れることから，心筋保護上若干問題があるとい方よう. したがって超低体温・低流量灌流法の方が，心筋保護の 観点からより安全な方法とい光る。

文 献 1) 村岡隆介湾力: 胸部外科 $34: 19,1981.2$ ) 許 俊鋭活か：日胸外会誌 $26: 449,1978$. 3) Neutze, J. M. et al.: Am. Heart J., 88 : 425, 1974.

\title{
B-30 乳幼児開心術の心筋保護液使用と非使用の臨床的評価
}

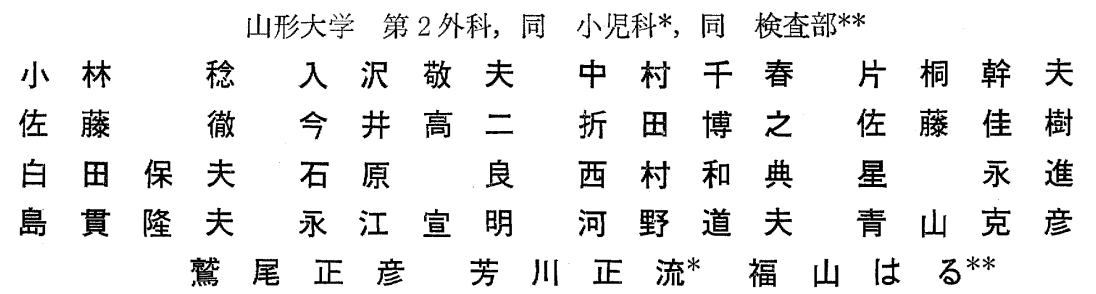

開心術における心筇保護としての cardioplegic solution p topical cooling の使用は ischemic cardiac arrest の間の (cellular damage) を軽減することがよく知られ ている．しかし，小児期，特汇乳幼児期の心臟手術に関 して, こ扎らの心筋保護液使用の臨床効果を研究, 検討 した報告は少ない，そこで著者等は最年少 2 カ月から 4 才未满までの開心術例 52 例を全身冷却, 心臟局所冷却 之心筇保護液 (GIK or GK) を施した群と全身冷却之 心臓局所冷却群のみの 4 群に分けて比較検討を行い, 若 干の知見を得たので竍告する。

\section{対象および方法}

$\mathrm{A}_{1}$ 群は 1 才以上，4才未満のファロー四徴 ( $\mathrm{TOF}$ ) 5 例，心室中陥欠損兼動脈管開存症 (VSD+PDA) 1 例, 完全型心内膜床久損症 (compl ECD) 3 例，心室中陥欠 損症兼肺動脈狭窄症 (VSD+PS) 2 例, 心室中陷欠損症 (VSD) 5 例の以上 16 例である. $\mathrm{B}_{1}$ 群は 1 才以上, 4 才未満の TOF 4 例, VSD+PDA 2 例, VSD+PS 1 例, VSD 6 例, compl ECD 2 例, VSD + MR (僧帽 弁閉鎖不全） 1 例の計 16 例である。 $\mathrm{A}_{2}$ 群は 1 才未満 の VSD 6 例，大血管転位症 (TGA)，僧帽弁閉鎖不全 症 (MR), PS+PDA の各 1 例の計 9 例である. $\mathrm{B}_{2}$ 群は 1 才末満の VSD 4 例, VSD+ASD 4 例, TGA 2 例,
$\mathrm{ASD}+\mathrm{Co} / \mathrm{Ao}$ (大動脈縮窄症) 1 例の計 11 例である. 以上の 4 群のうち $\mathrm{A}_{1} ， \mathrm{~A}_{2}$ 群に対して, 全身冷却 (cor cooling), 心臟局所冷却 (topical cooling), さら飞大動脈 遮断後大動脈基部より $5 \%$ 糖液 $1000 \mathrm{ml}$ 飞 $\mathrm{K}^{+} 20 \mathrm{mEq}$, Insulin 10 単位, $7 \%$ 炭酸水素ナトリウム $20 \mathrm{~m} l$ のい わゆる GIK 液あるいは insulin 拔きの GK 液の $4^{\circ}$ C の保護液を $5 \sim 8 \mathrm{~m} l / \mathrm{kg}$ をゆっくり注入し, 初回より 30 分ごとに同量注入した。一方 $\mathrm{B}_{1}, \mathrm{~B}_{2}$ 群は全身冷却 と心蔵局所冷却のみを行った。

$\mathrm{A}_{1}$ 群は体重が $9.9 \mathrm{~kg}$, 年令は 28.2 カ月, 体表面積 は $0.48 \mathrm{~m}^{2}$ であった． $\mathrm{B}_{1}$ 群はとれぞれ $10.7 \mathrm{~kg} ， 27.2$ カ月, $0.49 \mathrm{~m}^{2}, \mathrm{~A}_{2}$ 群は $6.5 \mathrm{~kg}, 9.4$ 力月, $0.34 \mathrm{~m}^{2}$, $\mathrm{B}_{2}$ 群は $6.1 \mathrm{~kg}, 8.6$ カ月, $0.33 \mathrm{~m}^{2}$ であった. $\mathrm{A}_{1}, \mathrm{~B}_{1}$ 群の間, $\mathrm{A}_{2}, \mathrm{~B}_{2}$ 群の間には有意差はないが， $\mathrm{A}_{1}$ と $\mathrm{A}_{2}$, $\mathrm{B}_{2}$ の間, $\mathrm{B}_{1}$ と $\mathrm{A}_{2} \mathrm{~B}_{2}$ の間には有意差が認められた（表 $1 \mathrm{a})$.

体外循環条件（表 $1 \mathrm{~b}$ ) は， $\mathrm{A}_{1}$ 群で希釈率 $23.3 \%$, 最低直腸温 $25.6^{\circ} \mathrm{C}$, 最低食道温 $22.7^{\circ} \mathrm{C}$, 灌流圧 60.6 $\mathrm{mmHg}$, 灌流量 $2.24 l /$ 分 $/ \mathrm{m}^{2}$, 灌流時間 120.8 分, 大 動脈遮断時間 72.9 分, 循環中尿量 $132.6 \mathrm{~m} l$, 循環中 $\mathrm{NaH} \mathrm{CO}_{3}$ 使用量 $48.7 \mathrm{ml}$ であった. $\mathrm{B}_{1}$ 群はそれぞれ， $19.2 \%, 26.1^{\circ} \mathrm{C}, 22.4^{\circ} \mathrm{C}, 58.2 \mathrm{mmHg}, 2.25 \mathrm{l} /$ 分 $/ \mathrm{m}^{2}$, 101.8 分, 53.9 分, $75.5 \mathrm{~m} l, 72.5 \mathrm{~m} l$ であった, $\mathrm{A}_{2}$ 群 
表 $1 \mathrm{a}$

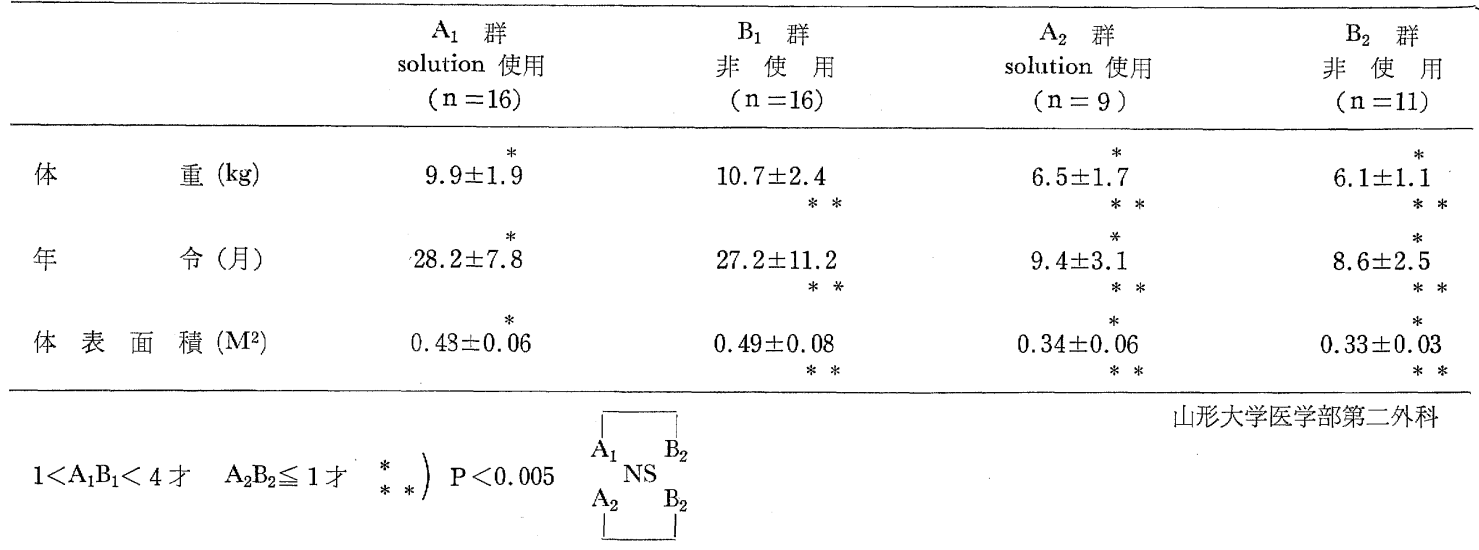

表 $1 \mathrm{~b}$

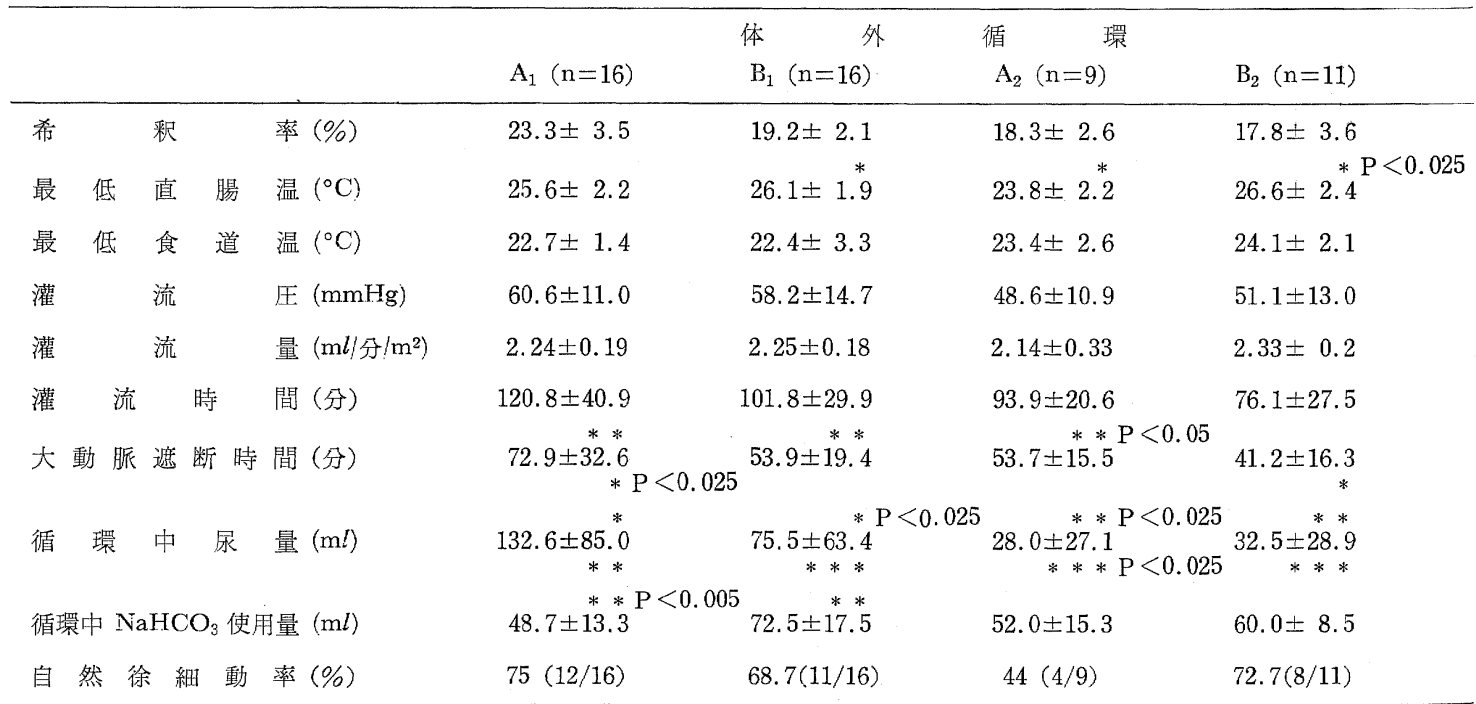

は $18.3 \%, 23.8^{\circ} \mathrm{C}, 23.4^{\circ} \mathrm{C}, 48.6 \mathrm{mmHg}, 2.14$ l分/ $\mathrm{m}^{2}, 93.9$ 分, 53.7 分, $28.0 \mathrm{ml}, 52.0 \mathrm{ml}$ であった. $\mathrm{B}_{2}$ 群は $17.8 \%, 26.9^{\circ} \mathrm{C}, 24.1^{\circ} \mathrm{C}, 51.1 \mathrm{mmHg}, 2.33$ $l /$ 分 $/ \mathrm{m}^{2}, 76.1$ 分, 41.2 分, $32.5 \mathrm{ml}, 60.0 \mathrm{ml}$, であっ た. 最低直腸温で $\mathrm{B}_{1}$ と $\mathrm{A}_{2}$ の間, $\mathrm{A}_{2}$ と $\mathrm{B}_{2}$ の間に有 意差が認められた。大動脈遮断時間で $\mathrm{A}_{1}$ と $\mathrm{B}_{1}, \mathrm{~A}_{2}$ の 間， $\mathrm{A}_{1}$ と $\mathrm{B}_{2}$ の間に有意差を認めた。 術中尿量で $\mathrm{A}_{1}$ と $\mathrm{B}_{1}$ の間, $\mathrm{A}_{1}$ と $\mathrm{A}_{2}, \mathrm{~B}_{2}$ の間に, $\mathrm{B}_{1}$ と $\mathrm{A}_{2}, \mathrm{~B}_{2}$ の間 そそれぞれ有意差を諗めた。 術中 $\mathrm{NaHCO}_{3}$ 使用量で $\mathrm{A}_{1}$ と $\mathrm{B}_{1}$ の間に有意差を認めた. 以上の症例に対して 術後第 3 病日までの尿量, 利尿剂使用量, カテコラミン 使用時間, 呼吸機使用時間, 心係数, CPK-MB の推移 について検討を加えた。
結果

体外循環からの自然徐細動率は各群間に有意差は認め られなかった。筋保護液使用群 $\left(\mathrm{A}_{1} ， \mathrm{~A}_{2}\right)$ のそれは 64 $\%(16 / 25)$, 非使用群 $\left(\mathrm{B}_{1}, \mathrm{~B}_{2}\right)$ は $70.3 \%(19 / 27)$ で両者 間にも有意差は認めなかった。術後第 3 病日までのカ テロラミン使用平均時間 $(2 \gamma /$ 分 $/ \mathrm{kg})$ は $\mathrm{A}_{1}$ 群 $27.7 \pm$

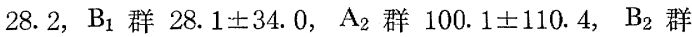
39. $4 \pm 51.3$ 時間で有意差は認められなかった。呼吸機

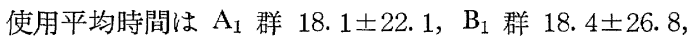
$\mathrm{A}_{2}$ 群 $70.6 \pm 77.4, \mathrm{~B}_{2}$ 群 $16.3 \pm 15.0$ 時間で有意差は認 めなかった。術中, 術後 CPK-MB の動態は図 $2 \mathrm{a}$ に 示したごとく，各群間には有意差は認めなかった。しか 

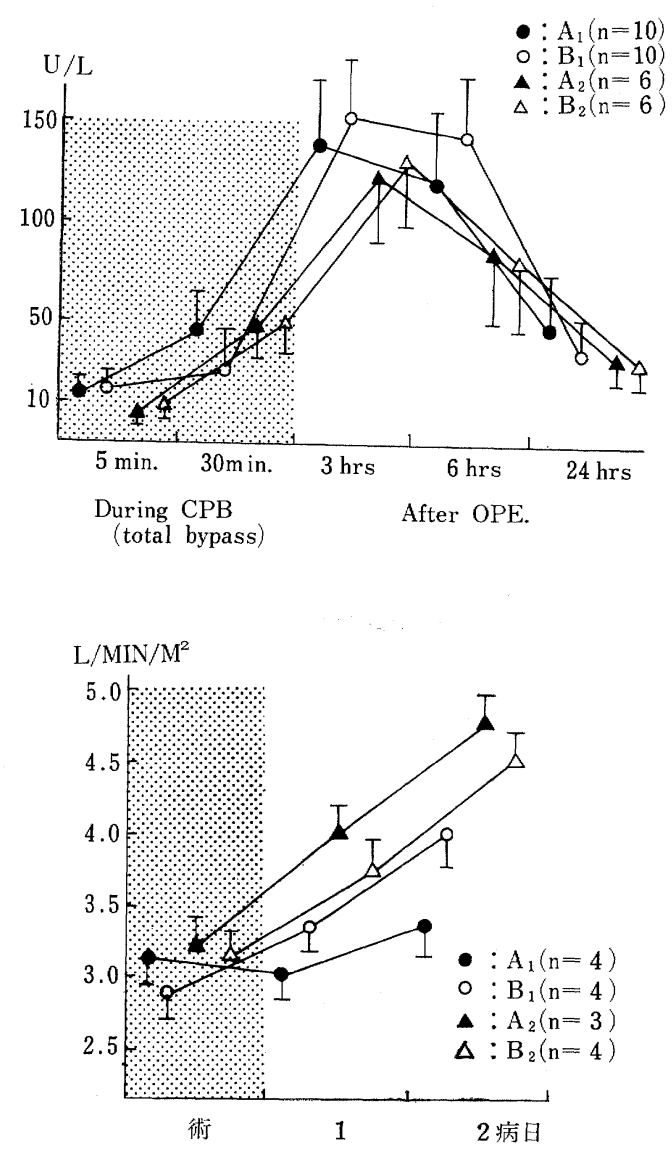

図 1

し, 開心術に执いて完全体外循環 5 分, 30 分, 術後 3 , 6, 24 時間で $\mathrm{MB}$ の出現を見るが $\mathrm{A}_{1}$ 群では 5 分で 10 例中 3 例, 24 時間では 10 例中 4 例の出現を認めな かった. $\mathrm{A}_{2}$ 群でも 24 時間值で 6 例中 2 例に 出現を認 めず， $\mathrm{B}_{1}, \mathrm{P}_{2}$ 群の場合より著明に出現が抑制されて和り 保護液使用の効果突恭い知ることが出来た。

術後第 2 病日までの術後 6 時間, 24 時間, 48 時間 での心係数は $\mathrm{A}_{1}$ 群 $3.16 \pm 0.28 l /$ 分 $/ \mathrm{m}^{2}, 3.02 \pm 0.7$, $3.45 \pm 0.55, \quad B_{1}$ 群 $2.82 \pm 0.65, \quad 3.32 \pm 0.60,4.03 \pm$ $0.85, \mathrm{~A}_{2}$ 群 $3.25 \pm 0.38,4.05 \pm 0.25,4.85 \pm 0.84$,

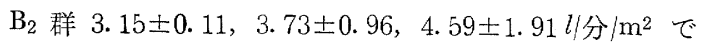
あって各群間に有意差は認めなかった（図 $2 \mathrm{~b}$ ).

時間尿量推移は $\mathrm{B}_{1}, \mathrm{~B}_{2}$ 群が $\mathrm{A}_{1}, \mathrm{~A}_{2}$ 群に比して多く排 泄され第 1 病日の $\mathrm{A}_{2}, \mathrm{~B}_{2}$ 間に有意差を認めた。 また 1 日の利尿剂使用平均は $\mathrm{A}_{1}, \mathrm{~A}_{2}$ 群が $\mathrm{B}_{1}, \mathrm{~B}_{2}$ 群比比して多 く使用しておう, 特に $\mathrm{A}_{2}, \mathrm{P}_{2}$ 群間で怡第 3 病日まで, いずれも有意差をもって $\mathrm{A}_{2}$ 群が多く使用していた。
考 $\quad$ 察
開心術の間の ishemic cardia arrest は心筋組織に damage をもたらすことが報告1)され，今日の上うに種 種2 4) の心筋保護液が各施設で使用されている. 成人で 心筋保護を施し, 良好な結果を得ている報告は多いが, 乳幼児期例汇対する報告 $\left.{ }^{5} 7\right)$ は少なく見解も定かでない， 心筋保護液の使用, 特に hyperkalemic solution は非生 理的動きによるATP の消耗を hypothermia の状態で, 急速な diastolic arrest にして ischemic の間の myocardial metabolism を抑制して ATP の消費を最少減にす ることを目的としている8). この保護液を使用すること に上り印象的には非常に良く思っているが, 自然徐細動 率, catecholamine 使用時間, 手術後早期死亡率などか ら評価しても, 非使用群との間注有意な差が得られな かった. ただ CPK-MB 值に対して検討すると, 各経 過中 $20 \sim 40 \%$ の割合で $\mathrm{MB}$ の出現を認めず，心筋保護 液使用が有用であったと判断し得た。しかし乳幼児例に 明解な差が出ないのは, cor cooling と topical cooling のみで充分に心筋保護效果至適温度に達しているためか， 肥大心の場合は成人でもそらであるが，乳児例でも術前 状態で右室肥大之両室肥大例が多く, 冷却が不十分なた めか, 心筋の特異性, 阻血飞対する耐容力, 温度飞対す る順応性，心筋代謝むるいは細胞膜の温度に対する反応 などなど種々雑多な要因があるために一様に判断され得 ないようにも思われる、今後これらの要因をらをえてさ らに症例を重初検討してゆきたいと思ら。

\section{おわりに}

1 才以上, 4 才未満の $\mathrm{A}_{1}, \mathrm{~B}_{1}$ 群之 1 才未満 $\mathrm{A}_{2}, \mathrm{~B}_{2}$ 群 を cor cooling, topical cooling z cardioplegic solution (GIK or GK) を使用した $A_{1}, A_{2}$ 群と cor cooling, topical cooling の及の $\mathrm{B}_{1}, \mathrm{~B}_{2}$ 群に分けて術中, 術後第 3 病日までのカテコラミン使用量, 呼吸器からの weaning 時間, 自然徐細動率, 心係数, 尿量, 利尿剤使用量, CPK-MB などから検討を加党, CPK-MB 值の出現抑 制が心筋保護液使用群に良好な結果が得られた。

文 献 1) Iyengar, S. R. K., Ramchand, S., Charett, E. J. P., Iyengar, C. K. S., and Lynn, R. B.: J. Thorac. Cardiovasc. Surg. 66:722, 1973. 2) Ellis, B. J., Born, M. Feit, T. Ebert: Circulation. suppl., 58: I, 1978. 3) Standeven, J. W., Jellinek, M., Menz, L. J., Hahn, J. W., Barner, H. B.: J. Thorac. Cardiovasc. Surg., $78: 893,1979$. 4) Braimbridge, M. V., Chayen, J., Bitensky, L., Hearse, D. J., Jynge, P., Darracott, S. C.: Thorac. Cardiovasc. Surg., $74: 900$, 
1977.5) 前田世礼, 北村惣一郎, 松田暉, 川島康生 : 日小外 会誌 18，981，1982. 6) 伊藤健二, 大川恭矩, 赤坂忠義, 清 水 進, 和気一夫 : 日胸外会誌 30, 162, 1982. 7) 小林 稔, 入沢敬夫, 中村千春, 佐藤徹, 折田博之, 佐藤佳樹, 星 永進,
鷲尾正彦：日小外会誌 18，1363，1982. 8) Laschinger, J. C., Catinella, F. P., Cnningham, J. N., Knopp, E. A., Nathan, I. M., Spencer, F. C., J. Thorac. Cardiovasc. Surg. 84 : 807, 1982 .

\title{
B-31 膜型人工肺と hemofiltration を併用した 体外循環の有用性について
}

\author{
高知市立市民病院 胸部外科 \\ 中 村隆澄 宮本信 昭
}

開心術炕際し，晶質性心筋保護液扣よび iee slush な ぞの心筋冷却法を使用することは，体外循環に比例して 稀釈率が元進するといら大きな問題が残る。体外循環に hemofiltration (HF) を使用することは自在に血液を濃 縮でき，きわめて有用な手段で劣る1)。われわれはこの とき血液破壊の少ないといわれている膜型肺との併用を 行い検討した.

\section{対象と方法}

症例は 3〜66 才までの開心術 83 例で，らち，高度腎 不全例 1 例之，無輸血例 16 例を含んでいる. 体外循環 時間 37 355 分，平均 142 分，手術死 3 例 (3.6\%) で あった（表 1 ).

体外循環は TMO 膜型肺と高速ローラーポンプを使 用し，無輸血例をのぞき稀釈率は 20〜25\% とした．体 外循環時間が 60 分をこ党ると思われる症例は，25〜 $30^{\circ} \mathrm{C}$ の低体温を併用した。

心筋保護法はヤング液にて心停止を計り，iee slush に よる局所冷却と， 30 分ごとの $4^{\circ} \mathrm{C} 500 \mathrm{ml}$ の $\mathrm{GIK}$ 液 で冠灌流を行った.

血液濃縮は体外循環回路比 poresize $60^{\circ} \mathrm{A}$, 膜面積 2.0 $\mathrm{m}^{2}$ のホローファイバー型人工腎 (Cordis: Hemo- Concentrator）を脱血側と貯血槽との間に並列に入れた。 小 型ローラーポンプにて流量 $200 \sim 400 \mathrm{ml} / \mathrm{min}$ ，陰圧によ る膜圧差 $90 \sim 400 \mathrm{mmHg}$ をか忛る限外汇過炕るもの である。

\section{結果}

体外循環 150 分をこえた 18 例について検討した. $\mathrm{Hb}$ の変動を $\mathrm{HF}$ 併用しなかった 10 例之の対比でみ ると, 後者では 15 分值 $8.1 \pm 0.4 \mathrm{~g} / \mathrm{d} l$ より 150 分值
$7.0 \pm 0.7 \mathrm{~g} / \mathrm{d} l$ と稀釈されていたのに対し,前者では 8.0 $\pm 0.5 \mathrm{~g} / \mathrm{d} l$ より $8.8 \pm 0.6 \mathrm{~g} / \mathrm{d} l$ と濃縮できていた（表 2-1). 150 分值江小て有意差 $(\mathrm{p}<0.05)$ をみた。

表 $1 \mathrm{HF}$ 併用の CPB (57.4.1 58.5.17)

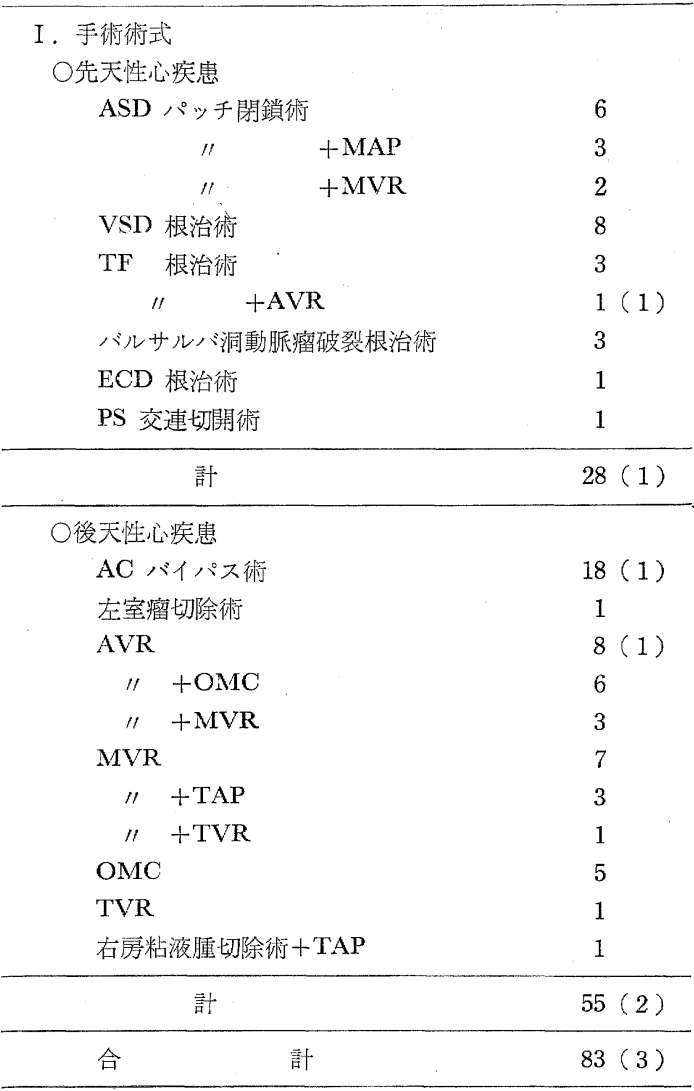

II. 体外循環時間

$37 \sim 355$ 分 $(\overline{142}$ 分 $)$ 